\title{
¿DEVELANDO EL LADO OSCURO?: LA NUEVA TECNOLOGÍA, LA INTERNET, LAS REDES SOCIALES SUS RIESGOS EN LOS NIÑOS, NIÑAS Y ADOLESCENTES ${ }^{1}$
}

\section{UNVEILING THE DARK SIDE? RISKS OF NEW TECHNOLOGIES, THE INTERNET, SOCIAL NETWORKS USE IN CHILDREN AND ADOLESCENTS.}

Juan J. Blossiers Mazzini²

La computadora a la venta en 1980, internet comercial con correo electrónico en 1990, tiendas virtuales en 1990, son algunos pasos de la internet. Sin embargo, sin necesidad de tecnología avanzada se ha sancionado a la televisión, y no es necesario mirar las "nuevas tecnologías" para poner en riesgo a los niños y las niñas; tan accesible ahora con los Smart o teléfonos inteligentes.

La televisión ha sido multada por no respetar el horario de protección al menor en los programas inusuales en otras latitudes como: “Tengo algo que decirte" y en un programa en que se utiliza el nombre de Dios en vano, denominado "Válgame Dios".

De manera que, las nuevas tecnologías no son la única forma de poner en riesgo a nuestros menores. Pensémoslo bien.

¿A quien consideramos niños en la ley peruana? Según el artículo primero del Título Preliminar se considera niño a todo ser humano desde su concepción hasta cumplir los doce años y será adolescente quien tenga de doce a dieciocho años. Como tales, son sujetos de derecho, con libertades y protección específica en base a políticas públicas buscando el interés superior del niño.

En el Perú, según el último censo del 2017, son niños y niñas 9’204,329 millones entre 0 y 17 años. De ellos $50.9 \%$ son niños y $49.1 \%$ niñas.

Ponencia presentada en el Pre Congreso Mundial de los Derechos de la Niñez y la Adolescencia organizado por el Colegio de Abogados de Lima y realizado el 7 y 8 de Setiembre de 2018.

2 Abogado por la PUCP. Especializado en Derecho Informático, y delitos informáticos, Pionero en Investigación Premio Internacional de la Federación Interamericana de Abogados con sede en Washington EEUU, 18 años de profesor en ingeniería, negocios y derecho. 
Veamos un poco de cifras: el $32.7 \%$ de 0 a 5 años son de la primera infancia; el 34.5\% de 6 a 11 años están en la niñez; el 35.8\% de 12 a 17 años son adolescentes.

En cuanto a la penetración del internet en los hogares, el censo de 2017, dio como resultados lo siguiente: el 50.5\% de los niños, niñas y adolescentes entre 6 y 17 años de edad usan internet. De ellos $52.4 \%$ son hombres y el $48.5 \%$ mujeres.

Además, el uso en zonas urbanas es de $64.2 \%$.

En cuanto a la diferencia de sexo: $66.1 \%$ hombres y $62.2 \%$ mujeres.

Mientras que en las zonas rurales el acceso a internet es: $18.1 \%$ hombres y 20.4 mujeres, $15.8 \%$.

Algunas aplicaciones más usadas por nuestros niños y adolescente tenemos:

Hi 5, Facebook, Twiter, Instagram, you tube, snap chat, whatsApp

Algunas palabras o cosas nuevas que tuvimos que aprender de nuestros niños:

Muro, Perfil, Trolear, Stokear, Fake, Follow, Friday, Meme, Cambiar de Estado, Snapchat, Youtubers, Influencers, Evento, Google Play, Hashtag, Trending Topic, Bajar videos, música, ver you tube, etc....

La pregunta que nos hacemos es: ¿dónde se presentan riesgos informáticos en los niños? La respuesta nos indica que la adicción se presenta en los juegos en línea, juegos interactivos con participantes remotos, en las cabinas de internet o en el hogar.

En cuanto a temas de índole sexual, podemos recordar el viejo dicho que se encuentra vigente: "no hables con extraños".

Nos preguntamos también si las redes sociales son una oportunidad o más bien un peligro como si se tratara de caminar rápido sobre piso mojado y resbaloso.

Se presenta también que se aprovecha de la inocencia e ignorancia de los niños que registran información e imágenes en las redes y existe, por lo tanto, peligro al publicar su intimidad. 
Muchos autores y expertos sustentan queel lado bueno, está en permanecer hiperconectados y su lado peligroso que escape del control del usuario.

Por ello, hay que enseñarle a los niños y adolescentes a usar la tecnología con prudencia.

\section{OPINIONES A FAVOR Y EN CONTRA:}

En la Doctrina especializada encontramos opiniones a favor y en contra:

\section{Algunas ideas a favor:}

Fernando García autor de la "Familia en el Ciberespacio", dice que debe haber un pacto, un acuerdo entre padres e hijos para su buena utilización.

Las redes sociales nos han cambiado. Se dice que lo que se definió en el cerebro digital fue una explosión, una eclosión de tecnología que no solo ha cambiado la forma de vivir sino de comunicarnos e inclusive altera nuestro cerebro a nuevas oportunidades que no deberíamos desaprovechar: información, la comunicación, las relaciones humanas, la economía, la educación.

Por ello, deben darse normas por los padres en el hogar, y autoridades educativas en los colegios, cuando, como, cuánto, y para que se usa la tecnología.

\section{Opiniones en contra:}

El neuropsicólogo Álvaro Bilbao en su exitoso libro "El Cerebro del Niño explicado a los padres", señala que los padres pueden permitir conscientemente o no la utilización excesiva de las redes sociales que crean infinita adicción lo alejan de la vida real, al punto que el niño percibe y cree más al mundo virtual que al real.

Ciertamente parece imposible frenar a un niño preadolescente de estar conectado a través de las redes sociales; porque en un niño de 10 a 13 años su cerebro comienza a experimentar una serie de estímulos y sensaciones, así como a disfrutar de la tecnología.

En casi todos los casos y con mayor precocidad, las chicas desean ser parte de un grupo y gustar del otro sexo, y es una parte fundamental de su identidad personal y social; por tanto, los niños quieren estar presentes en el mundo digital. Buscando aceptación en el grupo. 
Por ello, hay que buscar un punto de equilibrio; porque puede generarse la adicción que a simple vista no se nota.

Dentro de lo negativo del uso exagerado del internet es que les roba tiempo al estudio, a las tareas académicas, o al descanso.

Varios estudios serios han demostrado que estas tecnologías son adictivas.

Generan problemas de concentración, comportamiento, autocontrol, fracaso escolar. Pero tenemos que tener en cuenta que el empuje de la tecnología es imparable e incontestable.

Por ejemplo, uno de cada tres usuarios son niños. En el Perú 6 de cada 10 están expuestos a algún peligro en internet. Asimismo, también en Perú es posible que el $64 \%$ esté expuesto mientras que a nivel global la cibercriminalidad es de $47 \%$.

\section{PELIGROS DIGITALES}

Existen tres categorías de riesgos bien definidos:

a) Riesgos de contenidos, cuando un menor está expuesto a un contenido no deseado o inapropiado. Por ejemplo, imágenes sexuales, pornográficas, violentas, poco saludables o peligrosas.

b) Riesgos de contacto, cuando un menor participa de una comunicación arriesgada; por ejemplo, un adulto haciéndose pasar por menor o por un sexo diferente busca contacto inapropiado o se dirige a un niño para fines sexuales o que participe en conductas poco saludables o riesgosas.

c) Riesgos de Conducta, cuando el niño se comporta de manera que contribuye a que se produzca un contenido o contacto riesgoso como material inadecuado o publiquen imágenes de contenido sexual o material que ellos mismos reprodujeron.

Las TIC han ampliado los peligros tradicionales y creado nuevas formas de abuso y explotación infantil.

Por otro lado, es bueno señalar que los niños están desproporcionadamente afectados por los peligros en línea, incluida la pedida de privacidad. 


\section{RIESGOS DE LOS NIÑOS EN LA INTERNET DE CARÁCTER SEXUAL}

Existen los siguientes:

\section{a) Grooming:}

Es una nueva forma de comunicarse a través del cual un adulto se gana la confianza de un niño o de un adolescente con propósitos sexuales e inclusive sustituye su personalidad informática. Es un acoso sexual pero de manera lenta y progresiva.

Se gana la confianza, se involucra en situaciones de connotación sexual.

Se crean perfiles falsos. Se realizan chats, foros para buscar amistad, para buscar la confianza, es una estrategia de obtener concesiones de índole sexual. Proviene de groom quesignifica acicalar, preparar para minarlo psicológicamente al niño para conseguir el control emocional para un abuso sexual.

\section{b) Sexting o Sexteo}

Es el intercambio de fotografías, imágenes, o videos de contenido erótico entre los propios adolescentes o de un mayor de edad que finge ser adolescente para luego chantajearlo o extorsionarlo causando daños psicológicos importantes en el menor. E inclusive pidiendo intercambio de imágenes.

\section{c) Ciberbullying o Ciber Acoso}

Es el acoso entre menores en el internet con carácter local o global, supone un alcance que puede llegar a generar mucho daño no solo al menor sino a su familia y amigos.

\section{d) Pornografía infantil}

Redes internacionales que captan y filman material pornográfico con menores de edad con finalidad de comercio, exposición y distribución global.

\section{e) Usurpación de identidad o Impersonation.}

Reemplaza la personalidad digital de un niño, de un adolescente con el propósito de captar a la víctima con propósitos de atentar contra la indemnidad sexual y su libertad sexual. 
En nuestra legislación es regulada en el Artículo $5^{\circ}$ de la Ley $\mathrm{N}^{\circ}$ 30096 donde el sujeto pasivo son niños, niñas y adolescentes, en donde además debe probarse el dolo, conciencia y voluntad para lograr una sentencia condenatoria.

\section{f) Pedófilos on line}

Utilizan el mail, el video llamado, el chat, el Whats App, videos con propósitos o contenidos sexuales.

\section{g) Paliza Feliz}

Situaciones en que se agrede a un niño niña; violentamente se graba y se sube al ciberespacio o se transmite en vivo.

\section{EN EL DERECHO COMPARADO}

Existe el siguiente tratamiento normativo:

1. La Declaración de los Derechos del Niño, de 1959 que señala la protección de los menores contra los abusos sexuales.

2. Las Naciones Unidas en la protección de la infancia, donde la Convención Internacional sobre los Derechos del Niño de 20 de noviembre de 1989 explica sobre la doctrina de la protección integral y la doctrina de la situación irregular del menor.

3. La Recomendación N 1065 de 1987 del Consejo de Europa sobre el tráfico de niños y otras formas de explotación infantil.

4. La Convención del Derecho de los Niños de 1989, que en su artículo $1^{\circ}$ protege al menor de 18 años, incluyendo pornografía infantil, cualquier trabajo peligroso o que entorpezca su educación, su salud, su desarrollo físico, mental, espiritual o moral, así como el uso de estupefacientes y psicotrópicos.

\section{A MANERA DE CONCLUSIÓN}

En ese sentido, la tarea del derecho no es quedarse atado a las viejas categorías teóricas, sino más bien adaptarse y proveerse de nuevas formas de prevención y protección de la sociedad. 
Así, cobra completa vigencia las ideas del jurista, ex juez de menores, vocal superior Fermín Chunga Lamonja pionero en el derecho de familia que dijo: "Invertamos en los menores, son el presente y no el futuro". "Si uno lo hace, serán útiles a la patria y a la sociedad."

Demos tiempo y conciencia de este grave problema silencioso ya que estar vigilantes porque en internet no hay lugar seguro ciento por ciento. Nuestros niños nos lo van a agradecer.

\section{REFERENCIAS}

Barletta, María (2018). Derecho de la Niñez y Adolescencia; Lima: PUCP

Bilbao, Álvaro (2015). El Cerebro del Niño explicado a los padres. Plataforma Editorial. Barcelona

Chunga, Fermin, Chunga; Carmen, Chunga, Lucía (2016). Comentarios al Código del Niño y Adolescentes: Lima: Grijley

Fondo de las Naciones Unidas para la Infancia ( 2017). Niños en un Mundo digital. Nueva York: UNICEF

García Fernández, Fernando; Brindué Salo, Xavier ( 2002). La Familia en el Ciberespacio, Edit. Edu.com

Lins e Silva Paulo (2015). El Estatuto de la Familia en el Derecho Comparado. Revista Interamericana de Derecho Internacional y Comparado. Lima: AIDIYC

Save the children Perú (2017). Informe Young Voice Perú 2017, Lima, Perú: Ediciones Nova Print S.A.C.

Valencia, Jorge (2009). Justicia y Derechos del Niño. Chile: UNICEF

Fecha de recepción : : 28 de agosto de 2018

Fecha de aceptación : : 26 de octubre 2018 